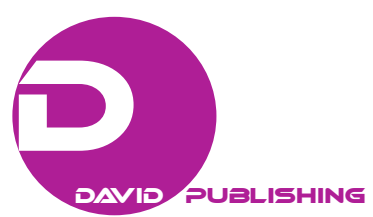

\title{
Semiotic Study of Taishan and Her Culture*
}

\author{
TIAN Fen \\ Taishan University, Tai An, China
}

\begin{abstract}
Symbols are representatives of a culture. The study of a culture is deeply rooted in its dynamic symbols. Different interpretations of a culture are always based on the understandings of the symbols. In order to depict Taishan culture effectively, this paper is a tentative study of explaining different symbols in Taishan and trying to communicate Taishan culture with the world.
\end{abstract}

Keywords: Symbol, Taishan Culture, Trans-symbolic Communication

\section{Introduction: Semiology and Semiotics}

Everything is socially connected by signs in the world, as signs are playing a very significant role in human communication and interaction. The study of signs is regarded as semiotics or semiology, being called in one another names according to different aspects of study preference. Of these studies, two particular representatives should be mentioned. They are Swiss linguist Ferdinand de Saussure (1857-1913) and American philosopher Charles Sanders Peirce (1839-1914). According to Saussure, Semiology was the study of how signs function in the social life, as:

It is ...possible to conceive of a science which studies the role of signs as part of social life. It would form part of social psychology, and hence of general psychology. We shall call it semiology (from the Greek semeion, sign). It would investigate the nature of signs and the laws governing them. Since it does not yet exist, one cannot say for certain that it will exist. But it has a right to exist, a place ready for it in advance. Linguistics is only one branch of this general science. The laws which semiology will discover will be laws applicable in linguistics, and linguistics will thus be assigned to a clearly defined place in the field of human knowledge. (de Saussure, 1983, pp. 15-16)

Comparatively, Peirce called the study of signs Semiotic, the formal doctrine of signs, which was closely connected with logic, as:

Logic, in its general sense, is ... only another name for semiotic, the quasi-necessary, or formal, doctrine of signs. By describing the doctrine as 'quasi-necessary', or formal, I mean that we observe the characters of such signs as we know , and ...by a process which I will not object to naming abstraction, we are led to statements, eminently falliable, and therefore in one sense by no means necessary, as to what must be the characters of all signs used by a 'scientific' intelligence, that is to say, by an intelligence capable of learning by experience. (Peirce, 1931-1958, P. 227)

So, the differences between Saussure's and Peirce's interpretation of signs are: As signs do not exist alone in society, they are interpreted together with meaning. Saussure proposed the term signifier and signified to refer to

\footnotetext{
* Acknowledgements: This paper is sponsered by Regulation Programme of Shandong Federation of Social Science Circles (山 东省社会科学规划研究项目) No. 14CWYJ10.

TIAN Fen, Lecturer, School of Foreign Languages and Literature, Taishan University
} 
the social relationship between signs and what they stand for. For him, signifiers are images and words whereas signifieds are concepts of these images and words. Everything in the world can be regarded as signifiers and they have some relationship with the signifieds. And this relationship is somehow indirect, and Saussure studies this relationship and illustrated it as arbitrary.

According to Peirce, people think only in signs, as signs take the form of words, images, sounds, ordours, flavors, acts or objects, but such things have no intrinsic meaning. Nothing is a sign unless it is interpreted as a sign.(Peirce, 1931-1958, p. 172) So, anything can be a sign as long as someone interprets it as signifying something meaningfully. And Peirce gave a further statement that signs related to objects by different levels of resemblance. These resembling levels were: icon as total resemblance; index as a casual connection; and symbol as conventional association. These three terms are called Peirce's Trichotomy (see Table 1)

Table 1:

Terms of Icon, Index and Symbol

\begin{tabular}{|l|l|l|l|}
\hline sign & Icon & Index & Symbol \\
\hline Signified by: & Resemblance & Causal connection & Convention \\
\hline Examples: & Pictures & Smoke / Fire & Words \\
\hline & Statues of great figures & Symptom / Disease & Gestures \\
\hline & Photo of Reagan & Red spots / Measles & \\
\hline Process: & Can see & Can figure out & Must learn \\
\hline
\end{tabular}

Therefore, Peirce studied more in details the relation between signifier and signified. As Arthur Asa Berger (1984) stated:

For Peirce, indexical relations and iconic relations are natural. Thus smoke is not merely 'conventionally' associated with fire, and iconic representations are, obviously, motivated. Only symbols are unmotivated. (p.13)

Thus, signifiers would be meaningful so long as they are motivated, and signified would make sense and be closely connected with signifiers if there exist motivations. And semiologically, icons are basic in understanding the motivation, index is more casual in motivated relation and symbols are of the most casual one, that is, unmotivated. So, the question is: If culture is taken into consideration, how to interpret it semiologically? The following would take Taishan culture for example and discuss the different motivated relations from Chinese and English understandings.

\section{Semiotic Study of Taishan and Her Culture}

Taishan was and still now is regarded as the most sacred mountain in China and was visited by emperors in different dynasties in Chinese history. Hence, her culture is of great value and the symbolic study of her culture is more of an importance in understanding Chinese history. Still, the further comparative study between Chinese and English way of interpreting the same sign in Taishan culture is a more practical and significant study to populate Taishan international cultural communication.

\subsection{Iconic Culture}

In Taishan, there are many famous pictures, maps and inscriptions which vividly denote the meaning of Taishan. The tablet inscription “五岳真形之图” (“Tablet of Five Sacred Mountain-Forms in China”) is one of 
the typical example. The tablet was inscribed to show the five sacred mountains regarded as the holiest and most auspicious direction in ancient China, as the Sun rises from the east. More than that, being also believed to be the grandson of the Emperor in Heaven, Taishan had the supremacy over all the world to govern the official posts of human beings, control the birth and death of life and deal with the length of the noble and evil spirits. (see Figure 1 and Figure 2)

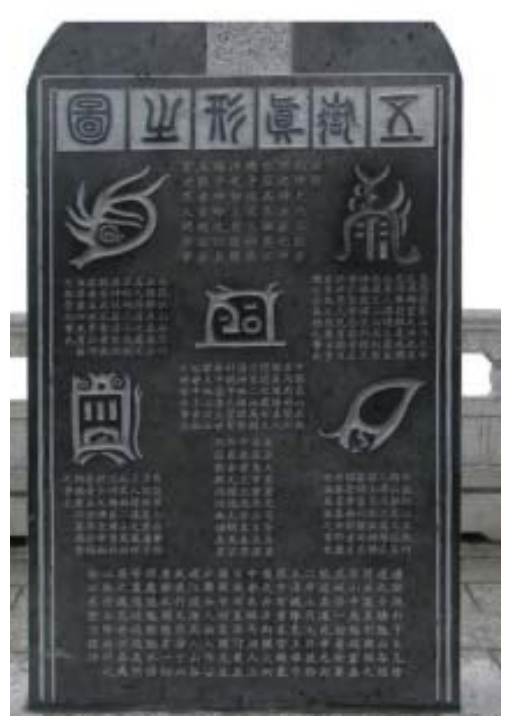

Figure 1. Tablet on the top of Taishan

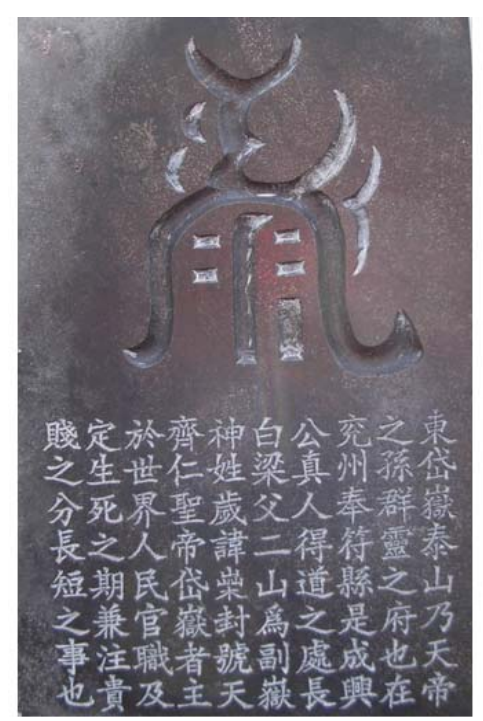

Figure 2. enlarged symbol of Taishan

From the tablet inscription, people believe that the icon of Taishan looks like a seated man who is facing the east and calls for the luck and auspice from the eastern direction, simultaneously gives control of human life. However, this interpretation is based on the traditional Chinese history books and records, such as Baopuzi (《抱 朴子》 $)^{1}$, quite different from the foreign cultures. So, the pictures or photos are closely connected with the culture that they belong to. Scholars from other countries would interpret it as maps of the five mountains respectively ${ }^{2}$, and they would not associate the maps with Chinese cultures spontaneously.

Similarly, when we come across stone inscriptions, as there are too many kinds of, in Taishan, what would we interpret? When we meet the Chinese characters inscribed as 虫二, how would we explain? Guo Moruo said that they are boundless beauties of nature (wind and moon), as 风 in ancient Chinese was written into 風, so 虫 and 二 are quite associative to the boundless 风 and 月, and still further, 风月 in Chinese language referred to natural beauty. Accordingly, the boundless beauty of nature is so appropriately explained.

Therefore, icons, pictures, and photos, though can be seen directly, they are closely related to culture and depict their culture and history. The native would understand the innate culture at the first sight of them. But the foreigner would in other case. A further thought is that iconic culture is deeply rooted in the particular life of human beings, which needs a further study and explanation when meeting with other cultures.

\subsection{Indexical Culture}

\footnotetext{
${ }^{1}$ by Ge Hong in Jin Dynansty. This book describes that Five Sacred Mountain are drawn as magic figures by Taoists to is for the Taoists to hold to expel evil spirits and bring good luck when they come into the mountains.

2 Such as Joseph Terence Montgomery Needham
} 
In Taishan, millions of pine tress grow to give shade and coverage of the mountain. Pine tree in Chinese culture stands for longevity and vividness of life. Whereas the more difficult to understand is that there exists a pine tree with officially the Fifth-rank (五大夫松). In Chinese history, it is easy to find official ranks for men, but odd for trees. In fact, this special pine tree was granted the official title by the first Emperor in Chinese history - Qin Shihuang. When he united the whole China, he came to Taishan for giving thanks to and worshiping good luck from the God in heaven. But on the way, he met with a heavy storm, so he had to hide under a big pine tree. He felt so grateful for the pine tree that he gave the tree the official rank. Interestingly, here this particular pine tree is no longer representing the traditional Chinese thought of long and live life, but a representative of gratitude. Whereas, the Fifth-rank is no longer conferred only to human but a typical example for a tree. Consequently, the indexical meaning with culture is always causal and to some extent though not completely, motivated.

Another example is also related to Qin Shihuang. On the summit of Taishan, there is a stone tablet called “Tablet Without Inscription” (“无字碑”) erected by following the order of this first Emperor. The traditional Chinese interpretation of stele or tablet was always about commemoration. However, there is no word inscribed in this stele, so different explanations would arise to consider the reasons and whys. Some scholars say that this stele was erected to show respect and offer thanks to the Emperor in Heaven, another say that Qin Shihuang was so great that no word to express his contributions. Whatever the sayings, this stone tablet is related to Chinese history and about Chinese culture. Comparatively, there also exists stone tablet in the western culture called "obelisk" which is about religion, commemoration or decoration. And in every side of the "obelisk", there always carved the pictographs, as if to remind people of the history. D. C. Baker once compared the Taishan tablet with the very famous obelisk - Cleopatra's Needles for "both in form and in age, the Taishan monolith can compare closely with Cleopatra’s Needles” (Baker, 1925, p. 122).

Generally, the indexical culture is also deeply rooted from history with causal and logical connections to certain historical evidences. Thus the different interpretations would be based on different cultures.

\subsection{Symbolic Culture}

According to Peirce, symbols are always unmotivated, so they are more closely related to a particular culture. Take the color green for example. Green was used to be represent Taishan in traditional Chinese beliefs as green stood for life and youth. Taishan situates in the east of China, and east is the origin and growth of life. In Chinese character, green is 青, like the freshness of vivid life growing. The famous Tang Dynasty poet Du Fu once eulogized Taishan “岱宗夫如何? 齐鲁青未了”. Thus, the color green is regarded as the symbolic representative of Taishan.

Another example is pilgrimage. In Merriam-webster dictionary, pilgrimage is: (1) a journey to a holy place; (2) a journey to a special or unusual place. Whatever the explanation, pilgrimage is a journey to some places of significance. In this way, the journey that people come to Taishan to worship can be viewed as a pilgrimage. However, this is a pilgrimage differed among people of different social status. This journey is called 进香 to an ordinary people as they took with them the paper money, gifts and incense to ascend to the summit of Taishan, gave all these to Bixiayunjun, the Goddess of Taishan as gifts and prayed to her for good health or child-bearing. These ordinary people would come from far and near, and they are called 香客 in Chinese. Whereas, the journey is only a way to purify or improve themselves for poets and literati, as they came to Taishan to enjoy and eulogize 
the greatness of the mountain, and expressed their feelings at the same time. This journey is quite a different pilgrimage for the Emperors as only those successful emperors had the right to come to Taishan for worship. Their pilgrimage was called 封禅 in Chinese. Interestingly, 封禅 are two different ceremonies, as 禅 was the ceremony held to worship all the souls in Hades in Mountain Haoli ${ }^{3}$ at the foot of Taishan, and 封 was the ceremony held on the top of Taishan to report the emperor's deeds, offer sacrifices and pray for prosperity of the country and peace of the people to the God in heaven. In short, the there would be different connotations for even the same word or phrase, and the word or phrase would be interpreted differently according to different cultures.

When taken symbolic cultures into account, the interpretation would be differentiated and a though learning of the particular culture is necessary.

\section{Semiotic-Cultural Communication}

\subsection{Background Information of Semiotic Culture Studies}

As symbols are so closely connected with culture, scholars carried out studies in semiotic-culture. A group of scholars in the University of Tartu had organized Summer Schools on Sign Systems from 1964 to 1972, in which Jurij Lotman did contributions to the establishment of Semiotics of Culture. From then on, the related study of methodologies, mechanisms and translations etc. had become focus of scholars and a great many findings have been published.

From the aspect of Semiotics of Culture, culture is dynamic especially in trans-cultural communication, if cultural symbols are deprived of, the trans-cultural communication would be stopped, which means, dead. And the very important position is the border in Semiotics, which is a bilingual one, through which, communications between symbols and non-symbols, the outer space can be contacted (Torop, 1999).

\subsection{Trans-Semiotic Cultural Communication}

Thus, cultural communication based on symbols is an effective way for interpreting the symbols and intercultural communication. In this way, whatever the symbols, if cultures are enclosed, the communication and interaction would be complicated. As for the same symbol, different interpretation based on cultures would be necessary. And this thought gives us a hint that when trans-semiotic cultural communication occurs, the explanation of the one's symbolic culture is of great importance.

A further point is that cultural communication based on symbols is dynamic. So, the trans-semiotic cultural communication is also developing with the social, economic and cultural improvement. Anyway it is associated and harmonious with one's cultural development. One of the Taishan cultural symbols which follow the style is Taishan Shigandang. Originally, Shigandang ${ }^{4}$ was regarded as a soldier who protected the Emperor in Wudai period in Chinese history, later he turned into a stone in Taishan, the most famous, sacred and respected mountain, thus the stones in Taishan were all called Taishan Shigandang for honoring the bravery and chivalry. Though there exist many other sources of origination, Shigandang was regarded as protective to drive off evils. People would call a stone from Taishan Shigandang. At present, Shigandang becomes more of a spiritual representative

\footnotetext{
${ }^{3}$ Also called Sheshou Mountain, a small mountain said to be the Hades.

${ }^{4}$ Shigandang

http://baike.baidu.com/link?url=xuundZ8ZMaJ8Ya90fpKNWa_AKb8UqsPCxHcOIA8aaqlKQ3RO7UaocPuIIggJiAofc1W3fdc5 HVuTQwRDALT5va
} 
than of a stone or a soldier. The spirit is to persevere and to protect the safety of the people and peace of the country. All in all, the interpretation and communication on the historical and original symbolic meaning is not enough. Trans-semiotic communication needs to be more developing and dynamic to meet with the change of the surroundings.

\section{Conclusion}

Taishan culture is abundant in symbols which help to shape the culture and to communicate with the world. Thus trans-symbolic cultural communication is a method to achieve the purpose. Conversely Taishan cultural symbols contribute to the study of Semiotics or Semiology.

\section{References}

Baker, D. C. (1925). T'ai Shan: An account of The sacred eastern peak of China. Shanghai, China: The Commercial Press. Berger, A. A. (1984). Signs in contemporary culture, an introduction to Semiotics. Annenberg: Longman Communication Books. Berger, A. A. (1992). Reading matter: Multidisciplinary perspectives on material culture. New Brunswick, NJ: Transaction Books. Berger, A. A. (1997). Bloom's morning: Coffee, comforters and the secret meaning of everyday life. Boulder, CO: Westview/HarperCollins.

Berger, A. A. (1999). Signs in contemporary culture: An introduction to semiotics (2nd ed.). Salem, WI: Sheffield.

Berger, A. A. (2009). What objects mean: An introduction to material culture. Walnut Creek, CA: Left Coast Press.

Chandler, D. (2001). Semiotics: The basics. London: Routledge. Semiotics for beginners. Retrieved from http://visual-memory.co.uk/daniel/Documents/S4B/the_book.html

de Saussure, F. (1983). Course in general linguistics (R. Harris, Trans.). London: Duckworth.

GUO, H. (2006). On cultural semiotics-Semiotic analysis of cultural semiotics. Shandong Foreign Language Teaching Journal, (3), 3-9.

Peirce, C. S. (1931-1958). Collected writings (8 Vols.). C. Hartshorne, P. Weiss, \& A. W. Burks (Eds.). Cambridge, MA: Harvard University Press

Torop, P. (1999). Cultural semiotics and culture. Sign Systems Studies, 27, 9-23. 